\title{
NIGERIA-CHINA: AN EXAMINATION OF RECENT BILATERAL TRADE RELATIONS
}

${ }^{1}$ Kabiru Hannafi Ibrahim \& ${ }^{2}$ Dyah Wulan Sari

${ }^{1}$ Department of Economics, Universitas Airlangga, Surabaya, Indonesia \& Department of Economics, Federal University, Birnin Kebbi, Nigeria

${ }^{2}$ Department of Economics, Universitas Airlangga, Surabaya, Indonesia

*Corresponding Author: Kabiru Hannafi Ibrahim

${ }^{1}$ Corresponding Author Email: hannafi.kabiru@yahoo.com

Article Received: 17-07-19 Accepted: 20-08-19 Published: 05-09-19

Licensing Details: Author retains the right of this article. The article is distributed under the terms of the Creative Commons Attribution-Non Commercial 4.0 License (http://www.creativecommons.org/licences/by-nc/4.0/) which permits non-commercial use, reproduction and distribution of the work without further permission provided the original work is attributed as specified on the Journal open access page.

\begin{abstract}
This study examines the trends, composition, and intensity of Nigeria-China bilateral trade for the period, 1992-2016. Tables, graphs, and trade intensity formula were used. The results show that Nigeria's trade with China has considerably recorded remarkable growth. With the exception of mineral fuels and products of their distillation, the share of major products exported to China over the period remained insignificant. More importantly, the results reveal that the share of major products imported from China remained significant, indicating that Chinese exports supply to Nigeria is more diversified than that of Nigeria's exports supply to China. Nigeria's trade intensity index shows a low possibility of increasing export to China and a high possibility of increasing import from China. In the case of China, there is exists a high possibility of increasing its export and decreasing its import to and from Nigeria. Based on the study's findings, the study recommends an urgent need for Nigeria's government to encourage export of various products in order to promote bilateral trade and mitigate the existing trade imbalance. The study further recommends the need for government, researchers, and export promotion agencies to identify new market opportunities for Nigeria's exports in the Chinese market.
\end{abstract}

Keywords: Bilateral trade, Trade Composition, Trade Intensity, China, Nigeria 


\section{INTRODUCTION}

Nigeria has remained one of the major trading partners of China in the whole African continent as it provides a market for various Chinese products. Diplomatic relations between the two countries was established in 1971. The two countries diplomatic relations was initially signed in 1972 in connection with technological and scientific co-operation. The operations of Chinese companies within Nigeria's territory has further strengthened the bilateral co-operation between the two countries. The relationship between Nigeria and BRICs (Group of countries comprising Brazil, Russia, India, China, and South Africa) of which China is among has risen in recent years because of the growing importance of Nigeria's oil and other opportunities available (Abiodun, 2011b). China's engagement into the Nigerian economy has led many to argue that its presence was meant to repeat what western world did to Nigeria and rest of African nations in the past that is to exploit Nigeria's resources (Thompson and Olusegun, 2014). But the fact is that Chinese focus and interest is on domestic economic development unlike the case of the Western World. As a result of this fact, Nigeria's trade is now shifting from (Europe, USA, and Canada) toward China, India, and Brazil. Nigeria and its traditional trading partners have come a long way in their cooperation and yet it is doubtful if such alliance has yielded any significant result to the Nigerian economy in terms of development (Ogunkola et al., 2008).

As at the time of conducting this study China is among the major trading partners of Nigeria. Trade between Nigeria and China has increased tremendously over the last few decades and has drawn attention and concerns of various researchers and policymakers in both countries. Over several decades the balance of trade between the two countries has been in favour of China and is likely to grow and continue with recent booming trade relations until Nigeria increase its competitiveness in the world markets. The main reason behind this trade imbalance in favour of China is due to different economic structures of the countries as manufacturing is an important feature of Chinese economy and oil characterized Nigerian economy (Mathias et al. 2012). Despite the trade imbalance between Nigeria and China, the two countries bilateral relations have not been bereft to unhealthy trade, unfair cooperation and increased exploitation (Ekesiobi et al., 2011).

Nigeria and China were giant economies in their continent aim to lead and become the world's top 20 economies in the near future to come. In term population, being the most populous country in Africa (Nigeria), and the most populous country in the world (China) both countries stands a better chance to gain from trade with one another. China has been among the world economic powerhouse since the on-going shift in global trade imbalance favouring developed countries at the expense of developing world, so also Nigeria can lead African continent given its available resources (Ekesiobi et al., 2011).

It is believed that there exists no bilateral trade between China and any of other African countries that are growing, and developing faster positive change and impacting on peoples' lives than the one that exists between Nigeria and China (Margaret and Qi, 2011).

With this in mind, the study aimed at examining bilateral trade relations between Nigeria and China with a view to analysing the trends, composition and trade intensity between the two countries. An analysis of this kind would enable further studies to have an understanding of the direction, magnitude, and nature of trade between Nigeria and China. 


\section{a. Theoretical review}

\section{LITERATURE REVIEW}

In countries' pursuit to gain from trade, countries end up gaining in not only the physical goods traded but also of capital flow and intellectual (Ekesiobi et al., 2011). According to the dependency and liberal economic theory, trade liberalization leads to an increase in the flow of goods, services and foreign investment (Mathias et al., 2012). In the early part of the $19^{\text {th }}$ century David Ricardo (1817), proposes a theory of the gains from trade also known as comparative advantage theory which cantered on the relative opportunity cost of production rather than the absolute cost of production. Ricardo's comparative advantage theory attempts to explain how trade can be mutually beneficial to countries. According to this theory trade between two countries will be mutually beneficial whenever the relative prices of commodities differ from country to country. A country can produce and export commodities which it can produce relatively cheaper in exchange for imports of those commodities that it produces relatively costlier. This process of producing and trading would lead to specialization by countries in commodities in which they have the greatest comparative advantage. The comparative advantage theory emphasized on the role of supply in international trade and take demand for granted until J.S Mill who introduced "Reciprocal Demand" which was later advanced by Alfred Marshall (Sunanda, 2010). Comparative advantage theory despite its flaws is still one of the most acceptable explanations of international trade.

The theoretical expectation of these theories is that countries at large will gain from trade either in the form of inter-industry trade or intra industry trade. Inter-industry trade is a trade in different industries by two or more countries. The level of countries engaged in this kind of trade is dependent on their comparative advantage. Intra-industry trade is trade in similar products by countries which the Heckscher-Ohlin model fails to explain. The model states that countries should export abundant resource products and import scarce resource products and intra industry trade involves the use of the same resources.

\section{b. Empirical review}

Some empirical studies conducted on Nigeria-China trade relations includes; (Djeri-wake, 2009; Mathias et al., 2012; Ayoola, 2013; Manjo and Devyani, 2014; Ogunkola et al., 2008; and Abiodun, 2011a). These studies were based on; examining the impact of Chinese investment and bilateral trade flow on Nigeria's economic growth, analysing the effect of Nigeria's higher imports over exports on the textile industry, measuring the effect of NigeriaChina trade imbalance on Nigeria's economic growth, examining the dynamic of trade in pharmaceutical among China, India, Pakistan and South Asia Free Trade Area Agreements, analysing the composition of Nigeria-China trade relations and an examination of NigeriaChina relations. Other studies similar to the current study were conducted by; (Ibrahim and Sayuti, 2017; Ibrahim and Abdulaziz, 2016; Ibrahim, 2015; Ibrahim and Dilfraz, 2014; Idris and Chukwuka, 2014; Ibrahim and Sayuti, 2017; Ibrahim and Iorember, 2018. These studies have examined trade intensity, composition and revealed the comparative advantage of Nigeria with its major trading partners like Brazil, China, India, Poland, and ECOWAS trading bloc. The results from the studies show evidence of low trade intensity on the part of Nigeria except for India in some years. The studies further indicate low diversified export on the part of Nigeria and that Nigeria can only competitively export mineral fuels to these 
countries and there is a partial match between its export supply and these countries' import demand.

Empirical studies on Nigeria-China bilateral trade have only used import and export data to measure bilateral relations between the countries. While the actual bilateral trade flow and the strength of trade relations can be measured using the trade intensity index. This is what most of the empirical studies on Nigeria-China trade ignored to look into while measuring trade relations between the countries. The only exceptions are studies by (Ibrahim and Sayuti, 2017; Ibrahim and Abdulaziz, 2016; Ibrahim, 2015; Ibrahim and Dilfraz, 2014; Idris and Chukwuka, 2014; Ibrahim and Sayuti, 2017.

It is against this background that this study would examine Nigeria's bilateral trade relations with China using trends analysis and trade intensity index in order to measure the strength of Nigeria-China bilateral trade relations.

\section{METHOD OF ANALYSIS}

This study relied on secondary data collected from the United Nations Commodity Trade Statistics (UNCOMTRADE) and access via the World Integrated Trade Solution (WITS). The data collected were based on $\boldsymbol{H S} 2$ digit level products for the periods 1992-2016. The methods of analysis in this study were based on the aims and objectives with which the study focussed to accomplish. The method of analysis includes the use of tables and graphs in order to analyse the recent trends in Nigeria-China bilateral trade relations using aggregate import and export data for the period 1992-2016. The same method was also used to analyse the structure, and composition of various commodities trade between the two countries.

Another important method of analysis used to measure the actual bilateral trade relationship between countries is the Trade Intensity Index (TII) which comprises of Export Intensity Index (EII) and Import Intensity Index (III). Nigeria's trade intensity with China is defined as the share of Nigeria's trade with China relative to the share of world trade with China and vice versa. The index, when computed, will serve as measure intimacy or relationship between Nigeria and China. The trade intensity index is measured by the following formula; -

$$
\boldsymbol{T I I}_{n c}=\frac{\underline{X}_{n c}}{\boldsymbol{X}_{w c} / X_{n t}}
$$

Where: $-\boldsymbol{T I I}_{\boldsymbol{n}}=$ is the Nigeria's trade intensity with China, $\boldsymbol{X}_{\boldsymbol{n} \boldsymbol{c}}=$ Nigeria's export to China, $\boldsymbol{X}_{\boldsymbol{w}}=$ World's export to China, $\boldsymbol{X}_{\boldsymbol{n}}=$ Nigeria's total exports, $\boldsymbol{X}_{\boldsymbol{w}}=$ World's total exports.

The trade intensity index is further divided into two, Export Intensity Index (EII) and Import Intensity Index (III), which can again be calculated as;-

$$
\boldsymbol{E} \boldsymbol{I I}_{n c}=\frac{\boldsymbol{X}_{n c}}{\boldsymbol{M}_{c t} /\left(\boldsymbol{M}_{w t}-\boldsymbol{X}_{n t}\right)}
$$

Where: $\boldsymbol{E}_{\boldsymbol{I}} \boldsymbol{I}_{\boldsymbol{n}}=$ Nigeria's export intensity index with China, $\boldsymbol{X}_{\boldsymbol{n} \boldsymbol{c}}=$ Nigeria's export to China, $\boldsymbol{X}_{\boldsymbol{n} t}=$ Nigeria's total exports, $\boldsymbol{M}_{\boldsymbol{c} t}=$ China's total imports, $\boldsymbol{M}_{\boldsymbol{w} t}=$ World's total imports, $\boldsymbol{M}_{\boldsymbol{n} t}=$ Nigeria's total imports.

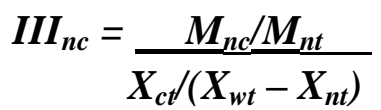

Where: $-\boldsymbol{I I I}_{\boldsymbol{n} \boldsymbol{c}}=$ Nigeria's import intensity with China, $\boldsymbol{M}_{\boldsymbol{n} \boldsymbol{c}}=$ Nigeria's import from China, $\boldsymbol{M}_{\boldsymbol{n} t}=$ Nigeria's total imports, $\boldsymbol{X}_{\boldsymbol{c} t}=$ China's total exports, $\boldsymbol{X}_{\boldsymbol{w} t}=$ World's total exports, $\boldsymbol{X}_{\boldsymbol{n} \boldsymbol{t}}=$ Nigeria's total exports. 
The trade intensity index always lies between zero and infinity (i.e. 0 to $\infty$ ). A high trade index shows a strong bilateral trade relationship between Nigeria and China while low index shows a weak bilateral trade relationship between Nigeria and China. For the export and import intensity index, an index of greater than one implies a better export and import possibility to and from China. While an index of less than one implies a weak export and import possibility to and from China. In short, the export and import intensities shows the relative importance of China to Nigeria in terms of China's demand for Nigeria's exports and the relative importance of Nigeria to China in terms of Nigeria's demand of China's goods.

\section{ANALYSIS AND PRESENTATION}

\section{a. Trends analysis of Nigeria-China bilateral trade}

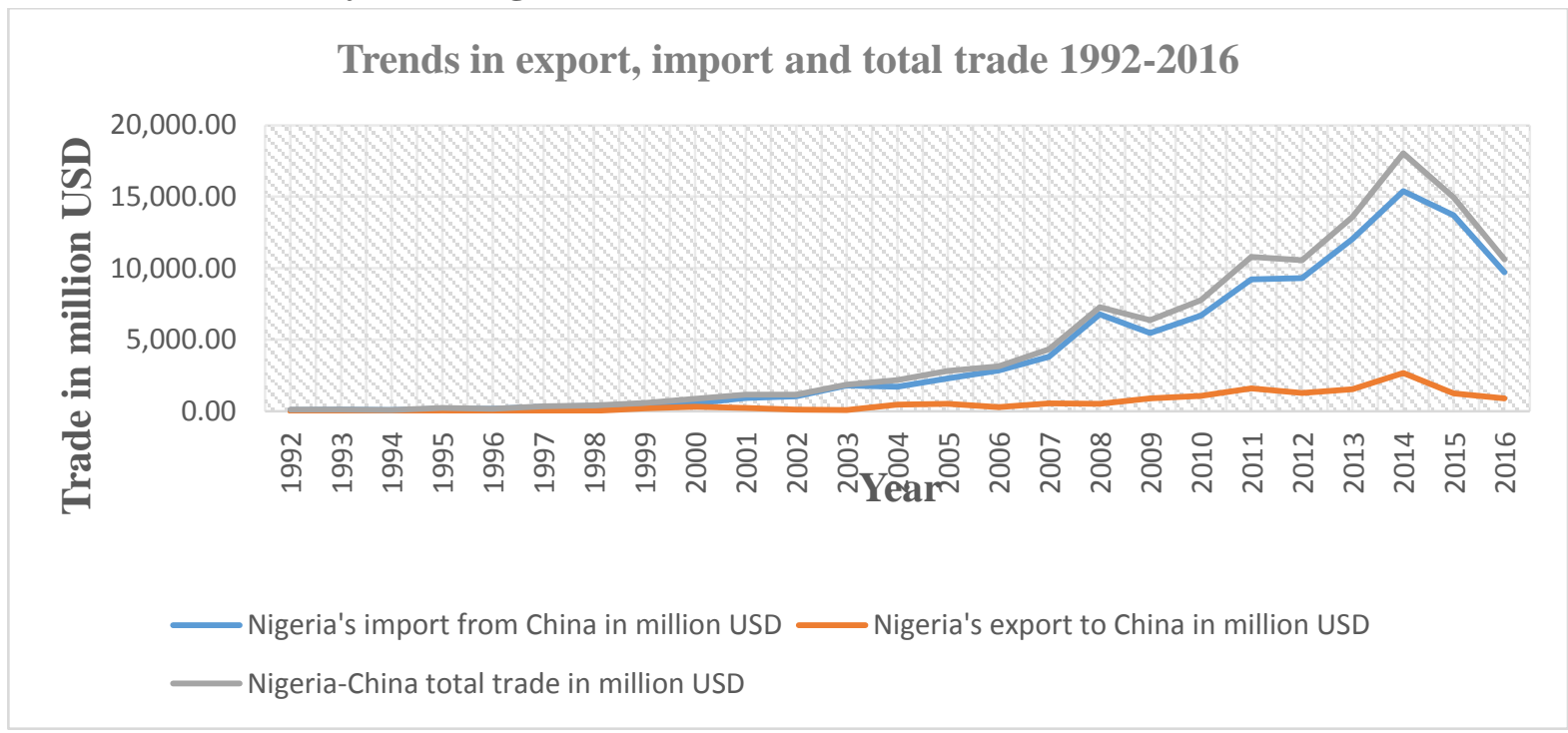

Figure 1: Trends in Nigeria-China Trade 1992-2016

Source: Author's Computation from UNCOMTRADE Statistics dated 29/12/2018.

An analysis of trade flow data in figure 1, reveals the trends in Nigeria-China bilateral trade relations of both imports, export and total trade for the periods 1992-2016. Nigeria-China bilateral trade has remained very low especially before the signing of a bilateral trade agreement between the two countries. Trade between the two countries has grown significantly after the signing of bilateral trade and investment promotion and protection agreement in 2001. Bilateral trade between the two countries reached a peak in 2014 with a total trade value of $\$ 18.05$ billion which declined to $\$ 14.94$ billion and $\$ 10.62$ billion in 2015 and 2016. This declined in bilateral trade was as a result of recent government policy which aimed at reducing importation of foreign manufactured goods. This impacted a lot on Nigeria-China trade as most the consumer goods in Nigeria were imported from China. In spite of all this, presently now, China is Nigeria's major source of import, as imports from China hits $\$ 13.7$ billion in 2015 though it declined to $\$ 9.7$ billion in 2016 . The increase in China's export to Nigeria is at the expense of Nigeria's traditional trading partners like USA, Canada, and Europe. In 2014, almost fifteen years after signing a trade agreement between Nigeria and China, bilateral trade increased almost 16 times its value before signing a trade agreement in 2001. Throughout the study periods, Nigeria imports more goods than it exports to China. 


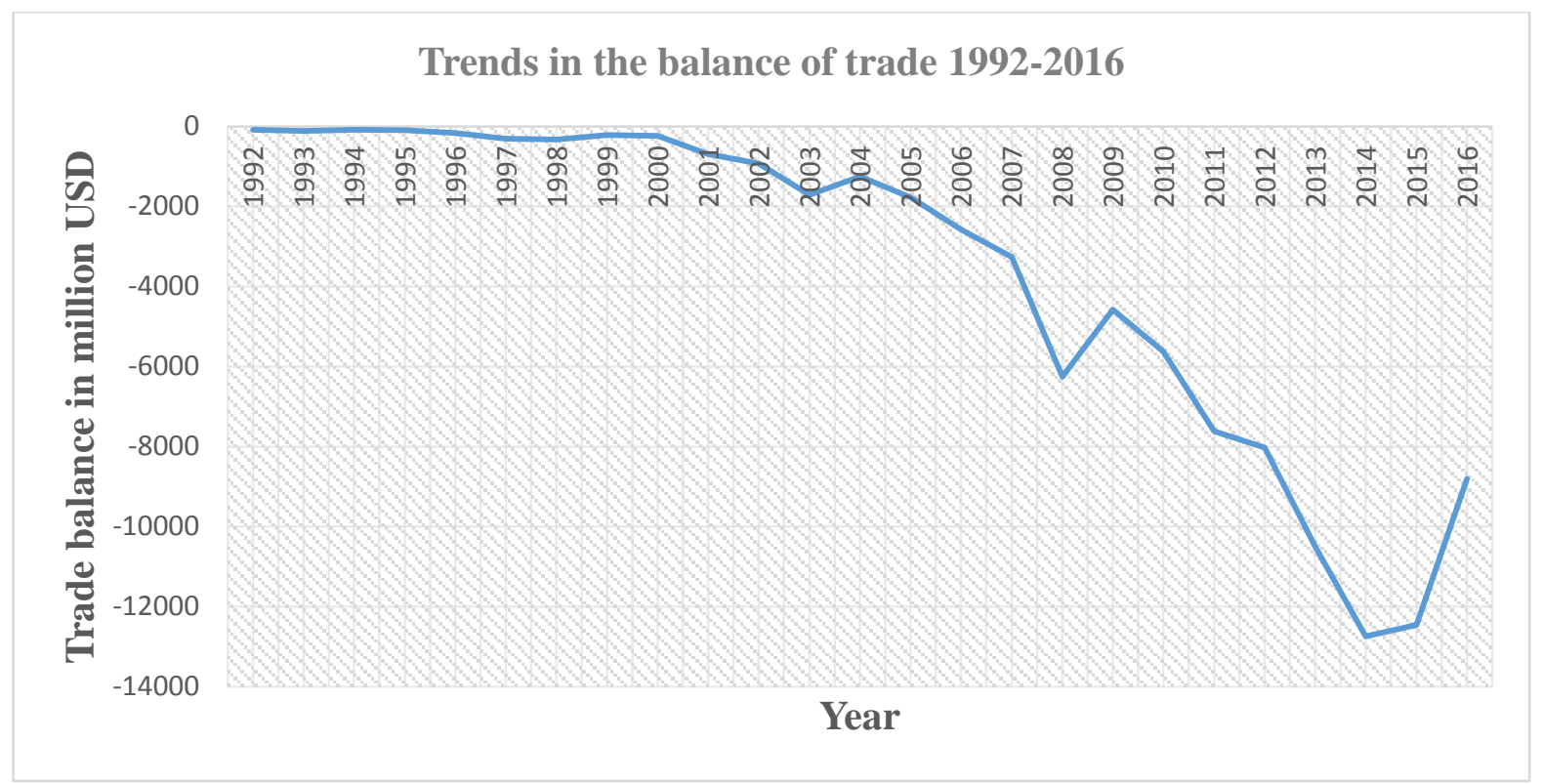

Figure 2: Trends in Nigeria's Trade Balance with China 1992-2016

Source: Author's Computation from UNCOMTRADE Statistics dated 29/12/2018.

Nigeria's export to China has not kept pace with its import as shown in figure 2. Therefore, there was never be a trade balance in favour of Nigeria and this trade imbalance has not only continued to increase but also intensified. Throughout the study period, Nigeria's import from China represented not less than $64.10 \%$ of the bilateral total trade. In 1993, of the total trade recorded, Nigeria's import from China represented over $99 \%$ with less than $1 \%$ representing its export share to China. This is a clear indication of trade balance been in favour of the Chinese economy. There was no improvement recorded after signing a bilateral trade agreement as the share of Nigeria's exports to its total trade with China worsened with a declined from $19.85 \%$ in 2001 to $8.51 \%$ in 2016 . This supported the result obtained by (Ayoola, 2013).

\section{Trends in the growth of import, export, total trade and balance of trade 1992-2016}

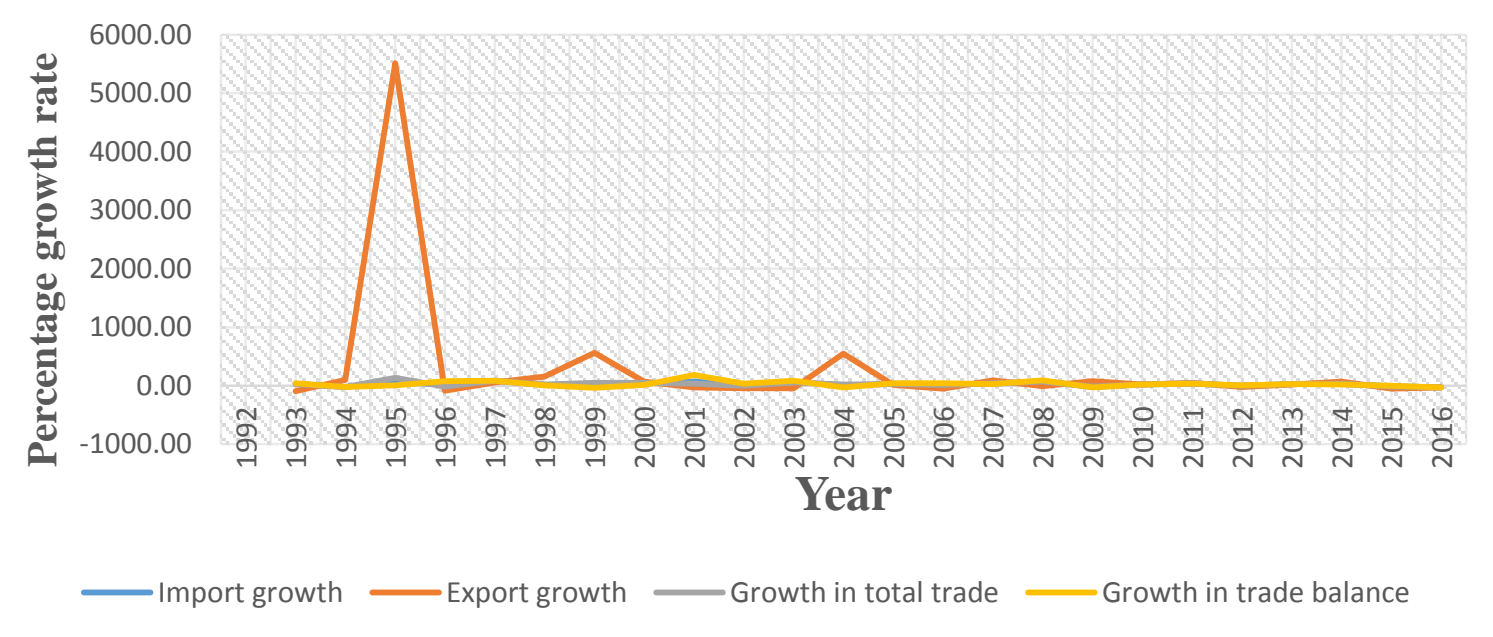

Figure 3: Trends in the growth of import, export, total trade and balance of trade 1992-2016

Source: Author's Computation from UNCOMTRADE Statistics dated 29/12/2018. 
Figure 3, depicts the trends in the growth of import, export, total trade, and trade balance of Nigeria's trade with China over the study periods 1992-2016. Based on the growth data and as evident from figure 3, Nigeria's trade with China experienced a boom from 1992-2016 despite the rising and falling trends throughout the periods. The highest export growth was recorded in 1995 which was a result of significant change in mineral fuels export as the product dominates Nigeria's export to not only China but to the rest of the world. Trade balance grows dramatically between the years 1995-1997 and 2000-2001. This massive growth in the trade balance is also reflected in the variation between exports and import to and from China which was, as a result, high import demand of Chinese goods by Nigerian with little export supply to China to match with increasing import. The growth in trade balance has since 2013 continuously declining and even turns negative in 2015 and 2016. This was as a result of the country's need to boost its export supply to not only China but to the world in general.

\section{b. Nigeria-China trade composition}

Table 1

Composition of Nigeria-China Trade 1992-2016

\begin{tabular}{|c|c|c|c|}
\hline $\begin{array}{l}\text { Main products of } \\
\text { Nigeria's exports to } \\
\text { China 1992-2016 }\end{array}$ & $\begin{array}{l}\text { Product share in the } \\
\text { total exports to China } \\
\text { 1992-2016 }\end{array}$ & $\begin{array}{l}\text { Main products } \\
\text { Nigeria's import } \\
\text { China 1992-2016 }\end{array}$ & $\begin{array}{l}\text { Product share in the } \\
\text { total import from } \\
\text { China } \\
\text { 1992-2016 }\end{array}$ \\
\hline $\begin{array}{l}\text { Mineral fuels \& product } \\
\text { of their distillation }\end{array}$ & 0.83 & $\begin{array}{l}\text { Electrical machinery \& } \\
\text { equipment }\end{array}$ & 0.18 \\
\hline $\begin{array}{l}\text { Wood and articles of } \\
\text { wood }\end{array}$ & 0.07 & Nuclear reactors \& boilers & 0.12 \\
\hline Ores, slag and ash & 0.05 & $\begin{array}{l}\text { Vehicles railway tram \& } \\
\text { roll-stock }\end{array}$ & 0.10 \\
\hline $\begin{array}{l}\text { Rawhides and skins and } \\
\text { leather }\end{array}$ & 0.01 & Articles of iron or steel & 0.05 \\
\hline $\begin{array}{l}\text { Copper and articles } \\
\text { thereof }\end{array}$ & 0.01 & $\begin{array}{l}\text { Aluminium and articles } \\
\text { thereof }\end{array}$ & 0.04 \\
\hline $\begin{array}{l}\text { Plastics and articles } \\
\text { thereof }\end{array}$ & 0.01 & Plastics and articles thereof & 0.04 \\
\hline $\begin{array}{l}\text { Oilseed, oleaginous } \\
\text { fruits; seed, fruit, etc. }\end{array}$ & 0.00 & Rubber and articles thereof & 0.04 \\
\hline $\begin{array}{l}\text { Rubber and articles } \\
\text { thereof }\end{array}$ & 0.00 & Iron and steel & 0.03 \\
\hline Cotton & 0.00 & $\begin{array}{l}\text { Art of apparel \& clothing } \\
\text { accessories }\end{array}$ & 0.03 \\
\hline $\begin{array}{l}\text { Aluminium and articles } \\
\text { thereof }\end{array}$ & 0.00 & $\begin{array}{l}\text { Furniture, bedding, } \\
\text { mattress, cushion, etc. }\end{array}$ & 0.02 \\
\hline
\end{tabular}

Source: Author's Computation from UNCOMTRADE Statistics dated 23/12/2018. ***Share below 0.01 was omitted by rounding up.

Nigeria's export and import to and from China comprise of various products categories which have been classified based on UNCOMTRADE 2-digit HS codes. But the major products exported to and imported from China between the years 1992-2016 are shown in table 1. Of all the major products exported, mineral fuels and product of their distillation accounts for the largest share and dominates the total export in the whole periods 1992-2016. This category of product alone accounts for 83 percent of total export. The next line of commodities exported was wood and articles of wood with a share of 7 percent of the total export. Ores, slag and 
ash account for 0.05 share in the total export while raw hides and skins and leather, copper and articles thereof, plastics and articles Thereof accounts for only 0.01 share in the total export. The remaining major products exported accounts for an insignificant share in the total export as their share in the total export fall below 0.1 or even zero throughout the whole periods. Looking at the share of Nigeria's export to China it was evident that mineral fuels and product of their distillation constitute the main product of all the major products exported. This implies that Nigeria's export was less diversified and supported the results obtained in studies by (Ibrahim and Sayuti, 2017; Ibrahim and Abdulaziz, 2016; Ibrahim and Dilfraz, 2014; Ogunkola et al., 2008).

The composition of Nigeria's import from China was largely different from that of its export though with little similarity in only three products category such as aluminium and articles thereof, plastics and articles thereof, rubber and articles thereof. Nigeria's import from China appeared to be fairly diversified as none of the major products imported from China constitute an insignificant share. Electrical machinery and equipment dominate Nigeria's import with a share of 0.18 in the total import. The second and third-ranked commodities were nuclear reactors and boilers, vehicles railway tram and roll-stock with a share 0.12 and 0.10 in the total import. Looking at the products share in the total import, Nigeria imports almost a significant amount of all the major products. This is because, of all the products, none of the products appeared with a share that is insignificant or of less than 0.02 in the total import.

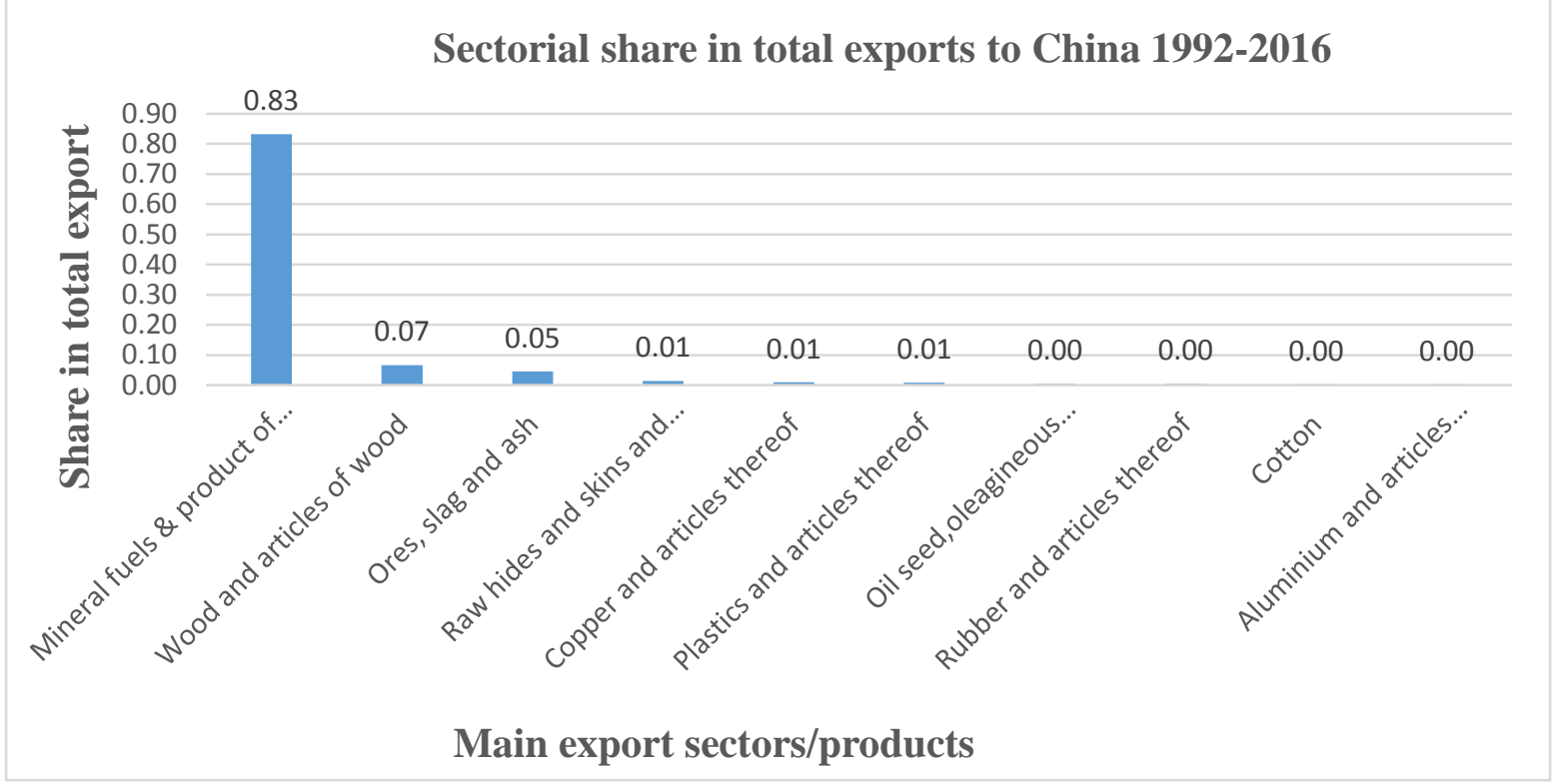

Figure 4: Main export sectors of Nigeria-China trade, 1992-2016

Source: Author's Computation from UNCOMTRADE Statistics dated 26/12/2018.

Figure 4, clearly shows the sectoral composition of ten major products of Nigeria's export to China based on $\boldsymbol{H S} \mathbf{2}$ digits product classification of $\boldsymbol{U N}$ COMTRADE. The most important export component is mineral fuels and products of their distillation which on average accounts for 83 percent of the total exports to China between the yeas 1992-2016. The second and third important products were wood and articles of wood and ore slag and ash which accounts for 7 and 5 percent of the total exports. The remaining seven major products exported despite being among the top ten major products exported their share to total export 
were quite insignificant with a share not exceeding 1 percent for the whole periods. The main reason for the low share recorded by these products is because of the fact that Nigeria exported more crude materials than any other products. The composition of Nigeria's export to China in 2016 was not only different from that of 1992 but with little repositioning of export to China. In trends term, the composition of Nigeria's export to China has not changed significantly over the study period considering the role played by mineral fuels in the Nigerian export between 1992 and 2016.

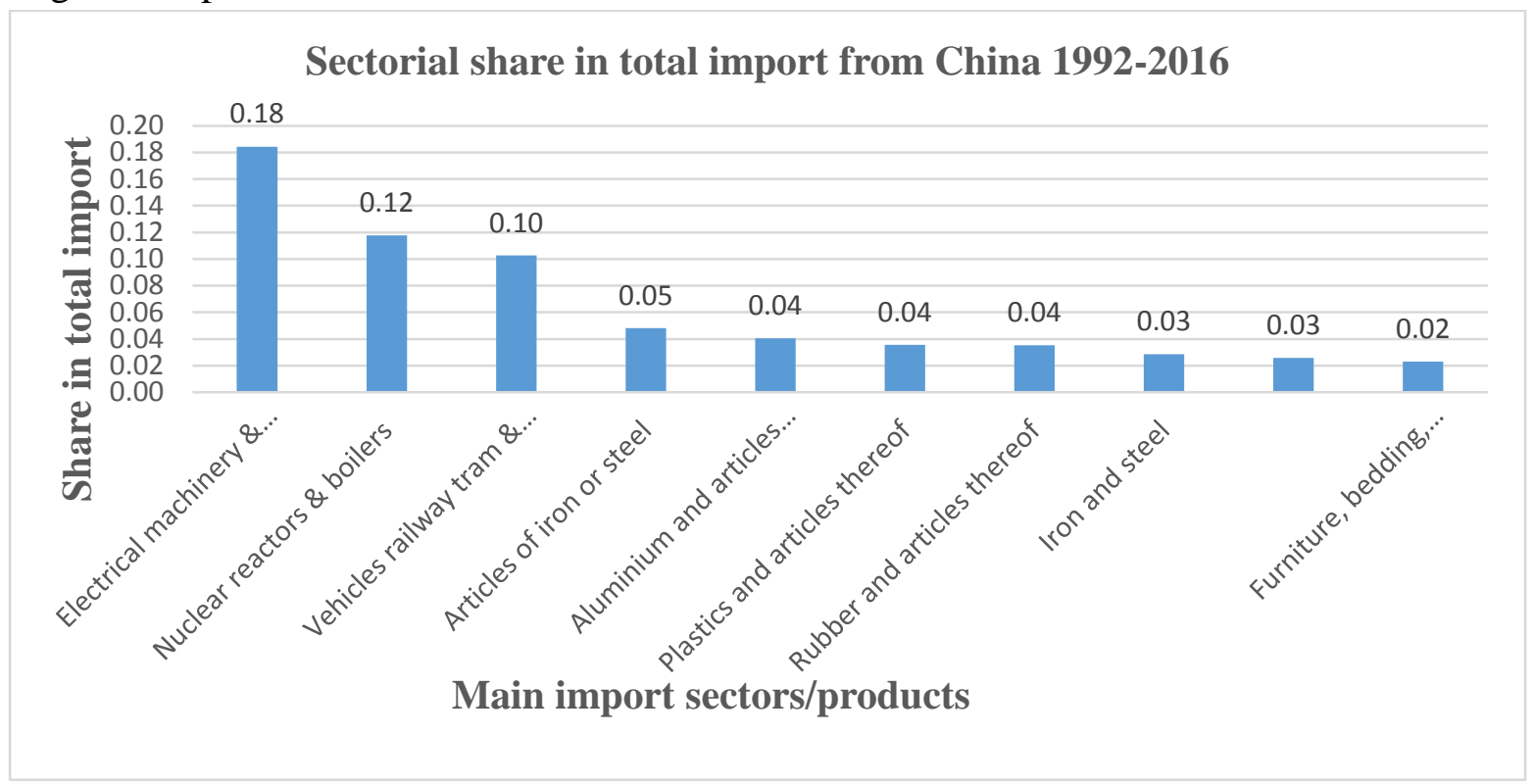

Figure 5: Main import sectors of Nigeria-China trade, 1999-2016

Source: Author's Computation from UNCOMTRADE Statistics dated 26/12/2018.

Figure 5, reveals that the export of China to Nigeria appeared to have been more diversified throughout the study period 1992-2016 based on the composition of Nigeria's import from China. Nigeria's import from China was dominated mostly by electrical machinery and equipment, nuclear reactors and boilers and vehicles railway tram and roll-stock. In terms of market share countries which exported such commodities to Nigeria has lost its market share in the Nigerian economy to China as the country is now increasingly meeting its import demand from China. The share of major products imported from China become more significant when compared with the major products exported to China. This because of the diversified nature Chinese export and non-diversified nature of Nigerian export. 


\section{c. Nigeria-China trade intensity}

Table 2

Nigeria-China trade intensity index 1996-2016.

\begin{tabular}{|c|c|c|c|c|c|c|}
\hline Year & $\begin{array}{l}\text { Nigeria's } \\
\text { TII with } \\
\text { China }\end{array}$ & $\begin{array}{l}\text { China's } \\
\text { TII with } \\
\text { Nigeria }\end{array}$ & $\begin{array}{l}\text { Nigeria's EII } \\
\text { with China }\end{array}$ & $\begin{array}{l}\text { China's EII } \\
\text { with Nigeria }\end{array}$ & \begin{tabular}{l}
\multicolumn{2}{l}{ Nigeria's } \\
III with \\
China
\end{tabular} & $\begin{array}{l}\text { China's III } \\
\text { with Nigeria }\end{array}$ \\
\hline 1992 & 0.04 & 0.57 & 0.02 & 0.56 & 0.57 & 0.02 \\
\hline 1993 & 0.00 & 0.72 & 0.00 & 0.74 & 0.72 & 0.00 \\
\hline 1994 & 0.00 & 0.66 & 0.00 & 0.68 & 0.66 & 0.00 \\
\hline 1995 & 0.23 & 0.98 & 0.16 & 1.00 & 0.98 & 0.15 \\
\hline 1996 & 0.04 & 0.99 & 0.03 & 1.05 & 1.10 & 0.02 \\
\hline 1997 & 0.00 & 1.45 & 0.00 & 1.43 & 2.55 & 0.03 \\
\hline 1998 & 0.24 & 1.47 & 0.17 & 1.76 & 1.11 & 0.14 \\
\hline 1999 & 0.58 & 1.62 & 0.39 & 2.47 & 1.06 & 0.35 \\
\hline 2000 & 0.22 & 1.69 & 0.15 & 2.35 & 1.04 & 0.30 \\
\hline 2001 & 0.27 & 1.90 & 0.19 & 2.58 & 1.44 & 0.30 \\
\hline 2002 & 0.13 & 1.70 & 0.09 & 2.28 & 1.58 & 0.13 \\
\hline 2003 & 0.14 & 2.21 & 0.10 & 1.97 & 1.16 & 0.05 \\
\hline 2004 & 0.32 & 1.67 & 0.23 & 1.69 & 1.66 & 0.20 \\
\hline 2005 & 0.26 & 1.59 & 0.19 & 1.60 & 1.58 & 0.17 \\
\hline 2006 & 0.00 & 1.56 & 0.00 & 1.45 & 1.61 & 0.07 \\
\hline 2007 & 0.33 & 1.41 & 0.26 & 1.25 & 1.61 & 0.14 \\
\hline 2008 & 0.07 & 1.73 & 0.05 & 2.51 & 1.59 & 0.08 \\
\hline 2009 & 0.24 & 1.64 & 0.19 & 1.53 & 1.71 & 0.20 \\
\hline 2010 & 0.25 & 1.70 & 0.19 & 1.32 & 1.50 & 0.12 \\
\hline 2011 & 0.29 & 1.76 & 0.22 & 1.23 & 1.33 & 0.12 \\
\hline 2012 & 0.83 & 1.80 & 0.60 & 2.05 & 1.78 & 0.08 \\
\hline 2013 & 0.18 & 1.96 & 0.12 & 2.01 & 1.73 & 0.15 \\
\hline 2014 & 0.23 & 2.24 & 0.16 & 2.33 & 1.63 & 0.22 \\
\hline 2015 & 0.33 & 2.33 & 0.24 & 2.20 & 2.32 & 0.19 \\
\hline 2016 & 0.20 & 2.30 & 0.14 & 1.84 & 1.38 & 0.22 \\
\hline
\end{tabular}

Source: Author's Computation from UNCOMTRADE Statistics dated 06/01/2019.

Table 2, shows that Nigeria's total trade intensity with China. Nigeria's export intensity is below 1 for the whole periods. This implies that Nigeria's total trade and export are less intense with China compared with the rest of the world. Nigeria's import intensity index in most of the years is greater than 1, implying high import potential from China. Nigeria's trade intensity indices (though below 1 for $\boldsymbol{T I I}$ and $\boldsymbol{E I I}$ ) have fluctuated over the study period 1992-2016. China got trade intensity index and export index of greater than 1 in almost the whole period except in the years 1992-2016. China's import from Nigeria falls below its export to Nigeria, this is reflected in the import intensity index as all the indices are below 1 . Looking at the trade indices computed trade have been more in favour of China than Nigeria with high potential of increasing Chinese export to Nigeria or Nigeria's import from China. 


\section{Trends in Nigeria-China trade intensity}

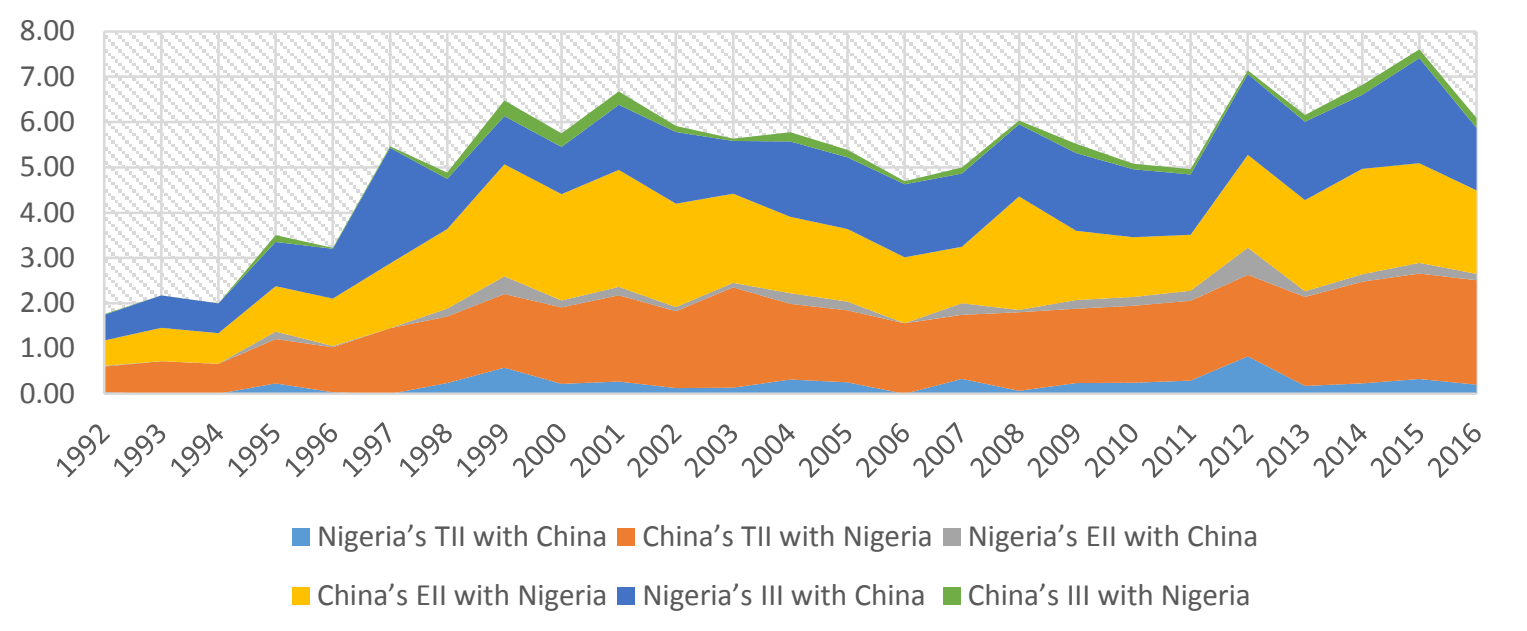

Figure 5: Trends in Nigeria-China trade intensity 1996-2016

Source: Author's Computation from UNCOMTRADE Statistics dated 06/01/2019.

Figure 5, depicts the time movement of Nigeria and China trade intensity indices. Nigeria's trade intensity except for import was smaller compared to China's trade intensity. Looking at the first two trends lines the indices have fluctuated throughout the study period. The width of each trend line measure the trade intensity as well as the trade benefits that go to the bilateral partner and trade potential. As depicted by the two middle trend lines Nigeria's export intensity is markedly lower than China's export intensity indicating more import from China than export.

\section{CONCLUSION AND RECOMMENDATIONS}

Nigeria-China bilateral trade has remained very low especially before the signing bilateral trade agreement. Trade between the two countries has grown significantly after signing bilateral trade, investment promotion and protection agreement in 2001. Despite the recent decline in bilateral trade, the current bilateral trade has surpassed the previous decades' bilateral trade in terms of size, impact, and relevance to the two economies. The study shows that Nigeria's export to China has not kept pace with its import from China as there was never be a balance of trade in favour of Nigeria and this trade imbalance has not only continued to increase but also intensified. Throughout the study period, Nigeria's import from China represented not less than $64.10 \%$ of the total bilateral trade. The trends movement reveals the highest export growth in 1995 which was the result of significant change in mineral fuels export as this product dominates Nigeria's export to not only China but to the rest of the world. The growth in trade balance has since 2013 continuously declining and even turns negative in 2015 and 2016. This was as a result of the country's need to boost its export supply to not only China but to the world in general. Of all the major products exported, mineral fuels and product of their distillation accounts for the largest share of $83 \%$ and dominates the total export in the whole periods 1992-2016. This implies that over the study period export to China was less diversified compared to import from China. The study further concludes that, looking at the trade indices the bilateral trade between the two countries has been in favour of China than Nigeria. Throughout the study period, Nigeria's export intensity have not been improved, implying that export to China has not been 
diversified. Looking at the Nigeria-China trade composition, the study recommends an urgent need for Nigeria's government to encourage the export of various products in order to promote bilateral trade and mitigate the existing trade imbalance. Considering the low export intensity possessed by Nigeria, there is a need for government, researchers, and export promotion agencies to identify new opportunities for Nigeria's exports in the Chinese market. This will help in diversifying Nigeria's export and strengthen trade relations between the countries. There is also a need for government and researchers to identify barriers faced by Nigeria's export to China in terms of an active bilateral trade agreement, tariff and non-tariff barriers.

\section{References}

Abiodun, A. (2011a). Nigeria and the Global Powers: Continuity and Change in Policy and Perceptions. African perspectives. Global insights. 1-28. Retrieved December 20, 2017

Abiodun, A. (2011b). Nigeria and the BRICs: Diplomatic, Trade, Cultural and Military Relations. South African Institute of International Affairs. Retrieved December 20, 2017.

Ayoola, T. J. (2013). Nigeria-China Trade Relations: Implication on the Nigerian Domestic Economy. Research Journal of Finance and Accounting, 4(17), 98-104. Retrieved April 1, 2019.

Djeri-wake, N. (2009). The Impact of Chinese Investment and Trade on Nigeria Economic Growth. Economic Commission for Africa, African Trade Policy Centre. African Trade Policy Centre. Retrieved March 6, 2018.

Ekesiobi, C. S., Ifebi, O. E., Ibekilo, B. C., \& Onochie, J. D. (2011). Dynamics of Foreign Trade and Trade Relation Problems: Policy Options for Nigeria. African Research Review, 5(1), 40-56. Retrieved March 7, 2018.

Ibrahim, K. H., (2015). Trade Complementarity and Similarity between Nigeria and India in the context of Bilateral Trade Relations. IOSR Journal of Economics and Finance (IOSR-JEF), VI (4), 28-32. Doi: 10.9790/5933-06642832

Ibrahim, K. H., and Dilfraz, S. (2014). Changing Perspective of Indo-Nigerian Trade Relations. Indian Journal of Applied Research, 4(7), 497-503. Doi: $10.15373 / 2249555 \mathrm{X}$

Ibrahim, K. H., and Sayuti, A. S. (2017a). Nigeria's Export Supply versus Brazil's Import Demand: 2000-2016. Ife Social Sciences Review, 25(2), 48-58.

Ibrahim, K. H., and Sayuti, A. S. (2017b). Nigeria's Trade Complementarity and Similarity with West African Sub-Region. Benue Journal of Social Sciences, 5(1). 122-138.

Ibrahim, K. H., and Shehu, A. (2016). Nigeria-India Bilateral Trade Relations: An Analysis of Trade Complementarity Index (TCI). Asian Journal of Economic Modelling, 4(4), 190-198. doi:10.18488/journal.8/2016.4.4/8.4.190.198.

Ibrahim, K. H., and Iorember, P. T. (2018). Sectoral and Products Wise Comparative Advantage in Nigeria-China Bilateral Trade Relations. Dutse Journal of Economics and Development Studies (DUJEDS), 6(1), 2536-6130. 
Idris, A., and O. Chukwuka, (2014). Nigeria-Poland Bilateral Trade: Identifying New Trade Opportunities. Centre for the Study of the Economies Africa. Retrieved November 7, 2018.

Manjo, P., and P. Devyani, (2014). India-Pakistan Trade: An Analysis of the Pharmaceutical Sector. Indian Council for Research on International Economic Relations.

Margaret, E., and Z. Qi, (2011). China and Nigeria: A Powerful South-South Alliance. West Africa Club. The Sahel and West Africa Club Secretariat (SWAC/OECD). Retrieved March 9, 2018

Mathias, A. E., Iwayanwu, O. J. Drenkat, K. N and Rong, S. L. (2012). Impact of foreign trade and investment on Nigeria's textile industry: The case of China. Journal of African Studies and Development, 130-141. doi:10.5897/JASD12.004.

Ogunkola, O. E., Bankole, A. S. and Adewuyi, A. (2008). China-Nigeria Economic Relations. Ibadan: African Economic Research Consortium (AERC).

Sunanda, S. (2010). International Trade Theory and Policy: A Review of the Literature*. Levy Economics Institute of Bard College.

Thompson, A., and Olusegun, S. (2014). China in Africa: An Evaluation of Chinese Investment. Lagos: Initiative for Public Policy Analysis. 